\title{
School Libraries to read the world
}

\author{
Elsa Conde \\ School Libraries Network Agency \\ Av. 24 de Julho, 140 1399-025 Lisboa \\ Portugal \\ elsa.conde@mail-rbe.org
}

\begin{abstract}
The main purpose of this paper is to present the intervention of the School Libraries Network Program in establishing projects and enlarged partnerships that leverage and consolidate the role of libraries in communities and open the students' access to knowledge and learning beyond the school boundaries. In this context a few examples are given and we describe some of the cooperative projects developed by the Program with different partners, public and private, in areas related to students' education and the construction of citizenship: reading, information, media, science, digital technologies, health, inclusion, heritage and others. These projects and partnerships are an important factor of strengthening, projection and sustainability of school libraries in the context of today's society and its new challenges.
\end{abstract}

O principal objetivo desta comunicação é apresentar o trabalho do Programa Rede de Bibliotecas Escolares (PRBE) no estabelecimento de projetos e parcerias alargadas que potenciam e consolidam o papel das bibliotecas na comunidade e ampliam as aprendizagens e o acesso dos alunos ao conhecimento para lá dos limites da escola. Neste contexto, são dados exemplos e descritos alguns dos projetos de cooperação desenvolvidos pelo Programa com diferentes parceiros, públicos e privados, relacionados com a educação dos alunos e a construção da cidadania nas áreas da leitura, informação, media, ciência, tecnologias digitais, saúde, inclusão, património e outras. Estes projetos e parcerias são um importante fator de fortalecimento, projeção e sustentabilidade das bibliotecas escolares no quadro da sociedade atual e dos seus novos desafios.

Keywords: School libraries; School Libraries Network Program; Partnerships; Projects; Cooperation

\section{Introduction}

The School Libraries Network Program (SLNP) was launched in 1996 by the Ministries of Education and Culture of Portugal. The program aimed at installing and developing libraries in state schools at every level, supplying its users with the necessary resources to read, access, use and produce information, whatever the format. 
Since its beginning the Program has left a mark of quality, highlighting the role of the school library in its multiple educational, informational, recreational and cultural functions.

Once consolidated the infrastructure of the SLN, consisting of over 2400 libraries, its development is currently undergoing according to a growing network philosophy, adopting a strategy of partnerships and joint projects of different size and scope (cultural, scientific, technological, artistic, ...) with universities, foundations, corporations, associations, media, public institutions and other organizations, through which one tries to combine synergies, enrich learning and enhance the integration of libraries in schools and society.

The field of education is not limited to teaching and pedagogy, including a variety of other practices and ways of intervention that, whilst acknowledging the centrality of the school, go beyond the strictly academic world and are today a condition to face the challenges of the contemporary world.

Current requirements to be successful in academic and professional life, civic participation in community life, for personal growth and cultural expression, are much more demanding, complex and extensive than in the past, and libraries must answer them reconfiguring as spaces for social inclusion and multidimensional building of individuals and knowledge. Libraries need to develop as real and virtual meeting places of discovery, learning and experimentation, open to the community and the outside world.

Hereby we describe different projects and partnerships set up by the SLNP that stimulate new logics and learning modes in schools, by mobilizing other entities with educational responsibilities to share with schools the task of educating and promote knowledge, science, culture and personal development of children and young people.

These projects involve entities such as the National Library of Portugal, the Calouste Gulbenkian Foundation and the Foundation for Science and Technology, the Pordata and the National Institute of Statistics, the Departments of Education and Health, and several universities, corporations and other organizations, covering different areas linked to the development of knowledge, skills and attitudes in reading, information, media, digital technologies, citizenship and curricula.

This idea of cooperation in accordance with the design of a public space for education promotes the development of projects and partnerships in school libraries, while non-formal learning spaces, beyond the space and time of traditional classrooms. Through them is intended to seek support and recognition to keep answering to a set of comprehensive knowledge and practice necessary for the integral education of students that courses only focused on curriculum goals cannot reach.

The education system needs more than ever of solid libraries capable of promoting the mastery of essential skills to face the challenges arising from the digital revolution and fight the social exclusion. The SLNP contributes to this goal through the development of new projects and partnerships, implementing policies, purposes and innovative intervention methods adapted to these challenges, which help students "to read the world". 


\section{Projects and partnerships}

It is recognized that cooperative work consolidates network organization, promotes the sustainability of each institution and turns its usefulness and social relevance more apparent.

The SLNP seeks to develop a network philosophy, through partnerships with other services of the Ministry of Education and Science, other educational agents, whether public or private, local authorities and civil society.

Through these partnerships the SLNP promotes innovation and excellence projects, which highlight a more skilled intervention in curricular learning, reading, ICT, information and media literacy and encourages citizenship.

Scrolling the large number and diversity of projects and partnerships established we've picked up a few representative examples.

\section{Reading projects: The project "aLeR+"}

The project "aLeR+" [Reading+], released in June 2008, is a joint initiative of the SLNP and Reading National Plan (RNP), in collaboration with the National Literacy Trust and the Reading Connects Project (UK), aimed at supporting schools that intend to develop an integral environment of reading.

The main objective is to place the reading and the pleasure of reading in the center of the school's educational projects and of its effort to raise levels of student's literacy, learning and educational success.

The project has been gradually extended to a greater number of schools (currently includes approximately 150 school clusters) with consistent reading practices.

The sustainability of the project is based on responsibility, participation and local involvement of schools boards, teachers-librarians, school library staff, teachers, employees, families, mayors, public librarians, animators, technicians and other cultural mediators as well as local entities (associations, corporations, etc.).

The main goal is therefore to give maximum visibility to reading in the school context, establish relationships with local communities, articulating efforts in promoting the pleasure of reading, and work with families to up hold reading at home.

The schools attached to the project benefit from suggestions and guidance materials, "aLeR+" certificate and logo, and financial support for the development of actions in schools. In "aLeR+" schools, libraries take on the dynamics of a bookstore, with frequent changes in the presentation of resources, with panels to highlight information, etc. The school entrance, corridors, classrooms and other spaces feature festive elements related to the project and the reading activities. The same happens in schools sites, blogs and in school newspapers, highlighting the importance of all types of reading.

The visibility and the centrality of reading are highlighted, for example, through the designation of classrooms with names of authors that students know and appreciate, the 
exhibition of photos of teachers, staff and students reading ("Caught reading"), the issue of interviews with local personalities about what they're reading, video presentation of books by readers, the inclusion of reading tips on school bulletin boards, aloud readings in different places, distribution of school kits with books and suggestions of useful sites, the exhibition of books with links to movies, music, and other art forms, reading passports and monthly disclosure of Top book and Top reader, setting up competitions and prize awards, etc.

The school teachers are part of the project in their school subject and actively promote reading in class and during school activities, acting as models. The work of the various courses covers the development of reading fluency in class and autonomous, and the pleasure of reading both in class as beyond it.

Libraries have the resources and organize activities for boys and girls as well as to the student's several cultures, backgrounds and mother languages. The information collected related to their readings is used to fulfill individual needs and customize counseling and books choice.

Students reading recommendations among themselves are also encouraged. Students are involved in the selection of reading resources and in the management of the library as monitors and encouraged to use the internet to publish comments and express opinions on books and other reading resources.

Exchanges between schools and older student's visits to previous level schools, with the aim of promoting reading progress from year to year or from cycle to cycle are also frequent.

Communities and book clubs for students are created to debate and share readings.

Parents, the all school teachers and the wider school community often participate in reading groups. Regular support sessions are provided for families and parents to choose books according to children's age and organize activities with the families.

Class tours are held to the public library and initiatives and common events are organized by them such as: writers' visits, book fairs, writing workshops, special date's celebration, etc. These strategies are intended to increase the use of libraries by students, as well as the number of books requests and the multiplication of reading experiences.

Every year take place in school and public libraries reading events linked to national events such as the World Book Day, the Children's Book Day, the Reading Week and the National Reading Contest.

Schools use network technologies and social networks to connect to other schools in reading projects, disseminate their practices and participate in the "aLeR+" annual national meeting which gathers the schools within the project.

The project "aLeR+" articulates with other partner projects in the context of reading, such as:

- the "Amostras para ler+" [Samples for reading+]: where moments are designed in the classroom, specifically to introduce books and support students on free choice of works for personal reading; 
- the "Ler+ jovem" [Reading+ youth]: together with the NRP and the University of Minho, it seeks to involve secondary level students on the choosing of texts and the promotion of reading activities among their communities elders;

- the "Ler, é para já!" [Reading, is right now!], which aims to motivate both young people and adults with limited reading habits that need to increase their literacy levels and consolidate the learning process required to their professional qualification or for reading pleasure, offering them specific suggestions of reading and activities;

- the "Voluntariado de leitura" [Reading volunteering]: created in 2012 by the New University of Lisbon, it intends to promote the development of a national network of volunteer work in the area of reading promotion, in which the school libraries have a key role in the volunteers catchment and framing.

\section{Media literacy projects}

Media projects are generally organized around annual contests.

The "Conta-nos uma história! - Podcast na Educação" ["Tell us a story! - Podcast on Education") initiative is a competition promoted by the Ministry of Education and Science, through the Department of Education, SLNP and NRP, with the Microsoft support.

This contest aims to design and develop digital audio and video resources arising from the creation of original stories or re-telling of stories, fables, parables, myths, legends or other existing texts.

The contest is targeted to Pre-school Education (3-6 years old) and 1st cycle Basic Education (7-10 years old).

The partnership between SIC Esperança and the SLNP, launched the initiative "Liberdade de expressão e redes sociais" [Freedom of expression and social networks].

This is a competition for the 3rd cycle Basic level and Secondary level students, aged 13 years old or more, with the presentation of collective work with original contents in text format, video, podcast, comics, photography or drawing under a previously defined topic. It intends to cause reflection on the essential nature of freedom of expression in democratic societies and the contribution of digital networks in widening access to information and interactive communication. It also intends to promote more ethical and responsible behavior, leading to the identification of risks and abuses arising from the misuse of social networking.

The contest "7 dias, 7 dicas com os media" [ 7 days, 7 tips on media] is an initiative promoted by SLNP in partnership with the Department of Education, the Foundation for Science and Technology and the Mass Media Agency.

The contest, open to all educational levels, aims to produce tips on media (alerts, recommendations, advises, etc.), using several formats (audio, video, electronic presentation or poster), aiming to foster in students the critical and creative use of the media, a safer use of the internet and the respect for copyright. 
In the media literacy scope we must also note the participation of the SLNP along with other entities in the "Literacy, media and citizenship" congress organization, whose 3rd edition runs April 2015.

\section{Digital literacy projects: the "ticEDUCA Júnior"}

School libraries are privileged spaces where activities promoting the ICT educational use take place. They constitute an essential structure for the development of digital literacy. The teachers-librarians are the engine of this work and it is crucial to share it and spread it.

In this context, the SLNP has signed, through the Competence Center for Technology and Innovation, a protocol of cooperation with the University of Lisbon - Institute of Education, aiming at the development of training activities for teachers in the educational use of digital technologies, through training actions, best practice seminars, workshops and other initiatives.

Under this partnership, a meeting takes place every year - the "ticEDUCA Júnior" [tic Education Jr.] in which teachers and teachers-librarians participate with their students in experiences exchanging, for discussion and reflection on the activities developed in schools.

In addition to this initiative, it should also be noted the existence in some school libraries of projects promoting reading, curriculum articulation and community liaison with a strong technological component and that were distinguished by the SLNP application as "Ideias com mérito" [Ideas with merit].

Actually in many school libraries the work done has long surpassed the settlement and organization level, developing projects that show a full use of the new available tools and devices (tablets, e-readers, smart phones...),, and allow the public presentation and spread of a wide set of good practices.

\section{Information literacy projects}

The partnership projects on information literacy focus mainly on providing diversified information resources, expanding the activities carried out in the classroom and placing the interdisciplinary dimension and the project work on schools agenda.

To promote information literacy it is needed to integrate it in teaching and learning activities. The inclusion of information literacy in the school curricula allows students to acquire transversal skills that can be deployable and transferable to new situations and cross-cutting contents which because of its nature, extent or complexity, can only be taught through a cross disciplinary approach.

Through the partnerships of SLNP with other entities, the teachers-librarians, teachers and students were sensitized and trained for the use of information resources and tools, improving the quality of their teaching and learning practices.

Pedagogic exploration of the statistical information as a source of active learning was the target of the collaboration established with two important institutions: the Statistics National Institute (SNI) and "Pordata". Through them teachers-librarians and other teachers were trained in the pedagogical use of a wide range of statistical information and digital resources 
made available by the Portal of the SNI, by the site of the "Local Action Applied Statistics" and by the "Pordata" database.

In 2010, the SLNP established a partnership with the Torre do Tombo National Archive in order to train the elements of the Program to replicate and spread in schools and libraries the information resources made available by this Archive.

The Project "REAtar" [Open Educational Resources - Technologies and Network Learning] also fits this purpose of enrichment of work opportunities on the information, aiming to capture the interest of teachers, school libraries and students for the use of the Digital National Library as a source of resources with high potential for teaching, learning and research.

Thus, actions have been developed to promote the use of this Digital Library in educational activities and beyond, in particular through the dissemination of contents of interest to the curricula, training and publicizing the Digital Library as a source for identification and construction, adaptation, reusing and sharing of open educational resources.

The contact with these primary sources allows students to understand every situation depending on the original perspective and realize the path as well as the multiple ramifications that a same resource led, contributing to the development of critical spirit and consolidation of attitudes of respect for the diversity of opinions generated by the same object.

The "Escola Virtual" platform [Virtual School] also offers a vast range of interactive features, supporting the self-study of students at different levels of education and disciplines.

School libraries can play a role in democratizing access to these learning resources, allowing all interested students who are unable to acquire a license, freely access the Virtual School in their school.

With this concern an agreement was established between the SLNP and the Virtual School, whereby it was defined a specific subscription plan for school libraries.

This plan is already running in several dozen libraries. By providing access to "Virtual School", school libraries have not only the opportunity to enhance the pedagogical use of their computing resources as they can also take advantage of promotional actions, having as goal the acquisition of skills needed to exploit digital educational resources as well as custom content development tools accessible on the platform.

In the recent past the schools were equipped with interactive whiteboards and other related initiative took place. To improve the use of those equipments in libraries and classrooms, the SLNP and Promethean Planet promoted the contest "Teaching and Learning with Interactive whiteboards - Flipcharts competition", inviting teachers-librarians and teachers to create sets of flipcharts and make them available in the Promethean Planet Portugal repository. 


\section{Curricular projects}

\section{The "Newton enjoyed reading!" project}

The project "Newton gostava de ler!" [Newton enjoyed reading!] is the result of a partnership between the SLNP and the Live Science Center of Aveiro.

Scientific and technological culture is increasingly recognized as a strategic condition for the development of active citizenship and as an engine of innovation and competitiveness into a more qualified society.

The project created an annual program of reading books in which science is present, creating bridges and motivations for holding small experimental actions, involving affordable materials and of simple replication in libraries.

With this project it was intended to promote the love for reading science books, scientific and technological culture, provide moments of experimentation and reinforce the collaboration between entities of formal and non-formal education of science.

Teachers and teachers-librarians involved in the project have training on the activities to be implemented in school libraries (books, contents, scientific topics and practical or experimental components). The Live Science Center of Aveiro develops all the content, programming and practical or laboratory activities, trains all teachers involved and supports implementing the program in libraries.

Apart from this project, arrangements were also established for the dissemination of resources and teachers training on scientific literacy with other Alive Science Centers, and the "House of the Sciences", managed by the Calouste Gulbenkian Foundation.

\section{The Project "SOBE"}

The Health Department, the National Reading Plan and SLNP established a cooperation protocol for oral health prevention in Portugal, formalized by the Project SOBE [School libraries, Oral health], linking oral health, literacy and school libraries.

It is well known the implications of literacy on health and well-being of citizens and the particular importance of health literacy in the educational field.

The project acts in this policy area with the following main goals:

- Target the promotion of reading, writing and oral health activities towards families and the community;

- Provide students as enablers of health promotion messages to their family members;

- Work oral health subjects in connection with the skills, attitudes and values of students in order to integrate "SOBE" principles in the everyday life;

- Arouse in students the desire to explore the real world of oral health in a funny way and by crossing of several fields of knowledge. 
The concepts of oral health can be strengthened in various ways and in different areas of the curricula. The project kits, consisting of books, games, DVDs and other materials allow a number of school activities that are able to draw the attention of students and teachers for the problems of oral health, through reading dynamics, dramatic expression, music, illustration, science, mathematical exercises,...; the participation of writers, illustrators, artists...; the liaison with vocational courses and the creation of multidisciplinary laboratories; the involvement of local authorities, municipal libraries, parents associations and other local entities; and the promotion of exhibitions, theatre festivals, competitions, training sessions, etc.

\section{The project "Know your city"}

Learn to act and better enjoy the urban space - that was the main challenge of the partnership launched between the Architects Order and the SLNP.

The promotion of a critical conscience and reasoned knowledge of issues related to urban and architectural heritage constitute nowadays a citizenship imperative. School libraries collaboration and cross-cutting action in the development of literacy and in access to knowledge makes them a privileged vehicle for the inclusion of these topics in the educational system.

The project proposed themes are: heritage, urbanism, and citizenship.

To develop the project "Conhecer a Cidade" [Know your City] a different range of resources and materials were provided such as: guides and book-games with guidelines, vocabulary, definitions, activities and several exercises challenging students to search, explore, discover and complete the missing information.

\section{Projects for inclusion: the "All together we can read" project}

The SLNP, NRP and the Department of Special Education and Socio-educational Support Services conceived a joint project called "Todos juntos podemos ler" [All together we can read]. Its main purpose is the creation of inclusive libraries able to provide reading opportunities for all students.

Faced with the increasing inclusion of students with special educational needs in regular schools, nowadays school libraries see themselves facing the absolute need of reply to a school population with diverse skills and that requires in many situations different technological means of access to reading.

The creation of inclusive school libraries, which provide real reading opportunities for all students, is perhaps one of the greatest challenges that school libraries have nowadays.

Developed with the cooperation of Portugal Telecom, the project main goals are:

- Endow the school libraries of suitable resources in different formats accessible to students with special educational needs;

- Develop best practices for the promotion of reading, taking into account the capabilities and needs of individual students in special education. 


\section{Conclusion}

The development and consolidation of SLNP in a social and cultural context very different from its origin twenty years ago have placed new challenges and requirements, to which we have tried to answer in a renewed way and with a network philosophy.

The articulation of the libraries with other institutions, the increase of relations with the surrounding communities, the cooperation with local authorities, civil society, and other government projects and educational agents are key assumptions of this innovative way of thinking and acting.

Today, the development of partnership projects is widespread and also one of the main factors for the SLNP strength and sustainability.

Through these projects, innovation and excellence are promoted in different areas, showing a more qualified intervention on improvement of learning, literacy and the schools and educational agents' engagement.

These partnerships enclose a large number of activities, such as learning, pedagogical and cultural animation, training, technical assistance, dissemination of information, provision of resources, sharing of knowledge, reading promotion and improving of students' multiliteracy.

As stated in the Strategic Framework of PRBE (Rede de Bibliotecas Escolares, 2013, p. 21):

"The cooperation of school libraries with other organizations (universities, libraries, museums, archives, associations, companies, etc.) and the participation in collective projects of different size and scope constitute an indispensable added value to their strengthening and integration in society.

At a time when the networks and digital tools favor the conjugation of synergies and the implementation of common projects and activities, the library is further enhanced by the sharing of resources, by establishing partnerships and profitable collaborative work".

The development of these projects and partnerships has contributed to:

- the enrichment of students learning experiences, training and socialization;

- the improvement of school libraries services and activities;

- the increase of communities and external partners' participation in the activities of libraries and schools;

- the growth of visibility, credibility and projection of school libraries into the local community and in society at large.

\section{References}

Rede de Bibliotecas Escolares (2013). Programa Rede de Bibliotecas Escolares. Quadro estratégico: 2014-2020. Lisboa: RBE. Retrieved from http://www.rbe.mec.pt/np4/np4/?newsld=1048\&fileName=978 972742366 8.pdf

Rede Bibliotecas Escolares. (n.d.). Portal RBE: 7 dias, 7 dicas com os media. Lisboa: RBE. Accessed from http://www.rbe.mec.pt/np4/1075.html 
Rede Bibliotecas Escolares. (n.d.). Portal RBE: aLeR+. Lisboa: RBE. Retrieved from http://www.rbe.mec.pt/np4/58.html

Rede Bibliotecas Escolares. (n.d.). Portal RBE: Amostras para ler+. Lisboa: RBE. Retrieved from http://www.rbe.mec.pt/np4/1109.html

Rede Bibliotecas Escolares. (n.d.). Portal RBE: Arquivo Nacional da Torre do Tombo. Lisboa: RBE. Retrieved from http://www.rbe.mec.pt/np4/ANTT.html

Rede Bibliotecas Escolares. (n.d.). Portal RBE: Conhecer a cidade. Lisboa: RBE. Retrieved from http://www.rbe.mec.pt/np4/cidade.html

Rede Bibliotecas Escolares. (n.d.). Portal RBE: Conta-nos uma história! Lisboa: RBE. Retrieved from http://www.rbe.mec.pt/np4/1066.html

Rede Bibliotecas Escolares. (n.d.). Portal RBE: Ensinar e aprender com QI. Lisboa: RBE. Retrieved from http://www.rbe.mec.pt/np4/1093.html

Rede Bibliotecas Escolares. (n.d.). Portal RBE: Escola Virtual. Lisboa: RBE. Retrieved from http://www.rbe.mec.pt/np4/1114.html

Rede Bibliotecas Escolares. (n.d.). Portal RBE: Ideias com mérito. Lisboa: RBE. Retrieved from http://www.rbe.mec.pt/np4/ideias com merito.html

Rede Bibliotecas Escolares. (n.d.). Portal RBE: Instituto Nacional de Estatística. Lisboa: RBE. Retrieved from http://www.rbe.mec.pt/np4/440.html

Rede Bibliotecas Escolares. (n.d.). Portal RBE: Ler, é para já! Lisboa: RBE. Retrieved from http://www.rbe.mec.pt/np4/123.html

Rede Bibliotecas Escolares. (n.d.). Portal RBE: Ler+ jovem. Lisboa: RBE. Retrieved from http://www.rbe.mec.pt/np4/568.html

Rede Bibliotecas Escolares. (n.d.). Portal RBE: Liberdade de Expressão e redes sociais. Lisboa: RBE. Retrieved from http://www.rbe.mec.pt/np4/1458.html

Rede Bibliotecas Escolares. (n.d.). Portal RBE: Newton gostava de ler! Lisboa: RBE. Retrieved from http://www.rbe.mec.pt/np4/Newton gostava de ler.html

Rede Bibliotecas Escolares. (n.d.). Portal RBE: Pordata. Lisboa: RBE. Retrieved from http://www.rbe.mec.pt/np4/1133.html

Rede Bibliotecas Escolares. (n.d.). Portal RBE: REAtar. Lisboa: RBE. Retrieved from http://www.rbe.mec.pt/np4/1114.html

Rede Bibliotecas Escolares. (n.d.). Portal RBE: SOBE. Lisboa: RBE. Retrieved from http://www.rbe.mec.pt/np4/sobe.html 
Rede Bibliotecas Escolares. (n.d.). Portal RBE: ticEDUCA Júnior 2015. Lisboa: RBE. Retrieved from http://www.rbe.mec.pt/np4/1105.html

Rede Bibliotecas Escolares. (n.d.). Portal RBE: Todos juntos podemos ler. Lisboa: RBE. Retrieved from http://www.rbe.mec.pt/np4/todos juntos podemos ler.html

Rede Bibliotecas Escolares. (n.d.). Portal RBE: Voluntariado de leitura. Lisboa: RBE. Retrieved from http://www.rbe.mec.pt/np4/voluntariado leitura.html

\section{Biographical note}

Elsa Conde has an advanced degree in Library Science and a master's degree in Educational Multimedia Communication. She has worked as teacher in Basic and Secondary schools between 1980 and 1995. In 1997 she joined the staff of the School Library Network Program as school librarian adviser and regional coordinator. She is coauthor of several documents published by the SLNP. She is responsible for monitoring of the SLNP cooperation project in Mozambique and Timor. She has also been a trainer in the area of libraries. Her main professional topics are reading, media and information literacy. 